\title{
Subjectivity in Japanese: A Corpus-Linguistic Study
}

\author{
Wenchao $\mathrm{Li}^{1}$ \\ ${ }^{1}$ Department of Japanese Studies, Zhejiang University, Hangzhou, China \\ Correspondence: Wenchao Li, Department of Japanese Studies, Zhejiang University, Hangzhou, China. E-mail: \\ widelia@zju.edu.cn
}

Received: June 26, 2019 Accepted: July 12, 2019 Online Published: August 26, 2019

doi:10.5539/ijel.v9n5p202 URL: https://doi.org/10.5539/ijel.v9n5p202

\begin{abstract}
This paper provides a corpus-linguistic study on subjectivity in Japanese, in an effort to arrive at how subjectivity, transitivity and grammaticalisation are related. 899 lexicons from nine grammatical categories (suffixes and prefixes, adjectives, particles, auxiliaries, nouns, adnominals, adverbs, and transitive/intransitive verb pairs) are examined. The findings reveal that Japanese is a subjective/objective-split language, and that subjectivity in affixes is facilitated by phonology: voiced/voiceless consonant alternation. The data also show that consonant-voiced prefixes and suffixes yield a subjective reading, while consonant-voiceless prefixes and suffixes render an objective meaning. Split subjectivity in adjectives is realised by morphology: Lい-ending adjectives tend to be subjective, while $い$-ending adjectives are mostly objective. The differentiation of subjectivity in adjectives is further tied to the constraints on personal pronoun and verbalisation possibilities. Intriguingly, objective/subjective readings of $し い$-ending adjectives and $い$-ending adjectives are switchable. Furthermore, among transitive/intransitive verb pairs, intransitive verbs are likely to get grammaticalised, while transitive verbs are likely to be lexicalised and thus render a subjective reading. This is confirmed by change-of-state verbs and motion verbs. This paper therefore puts forward the hypothesis that the interrelationship of grammaticalisation and lexicalisation is orthogonal.
\end{abstract}

Keywords: subjectivity, grammaticalisation, Japanese, corpus

\section{The Point of Departure}

Subjectivity has long been an important issue in studies on discourse. The term 'subjectivity' was put forward by Benveniste (1971, p. 224), who defined it as the psychic unity that transcends the totality of the actual experiences it assembles and that make the permanence of the consciousness. Lyons (1977, p. 739) argues that subjectivity represents as devices whereby the speaker, in making an utterance, simultaneously comments upon that utterance and expresses his attitude to what he is saying. Langacker (1987, p. 129) demonstrates from a cognitive linguistic perspective that, the more inconspicuous the existence of the speaker is, the more subjective an expression is. Traugott (2010) holds the view that expressions of subjectivity and intersubjectivity have the prime semantic or pragmatic functions of indexing both the speaker's attitude or viewpoint (subjectivity) and the speaker's attention to the addressee's self-image (intersubjectivity). Example (1) below maps the relationships between subjectivity, intersubjectivity and objectivity.

(1) Subjective - Intersubjective

- Objective
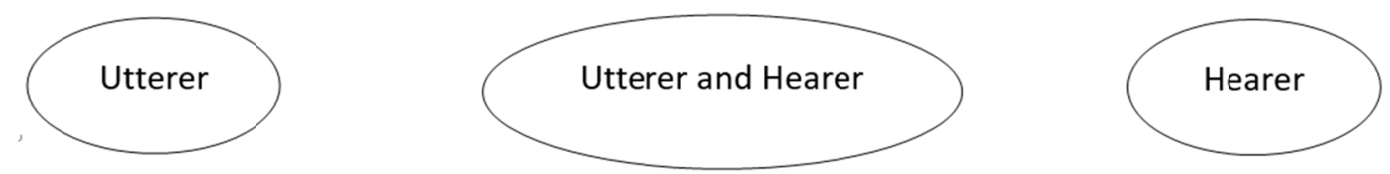

The study of subjectivity in Japanese is of particular interest for the following reason. It seems that nearly all grammatical categories in Japanese present a split subjectivity, i.e., transitive/intransitive verb pairs, adverbs, prefixes, suffixes, adnominal adjectives, particles, nouns, adjectives and auxiliaries. Below is a clear illustration of subjectivity in suffixes, adjectives and adnominals.

\section{(2) Split subjectivity in Japanese suffixes}

An immediate example that springs to mind is the nominalisation suffix pair: 〜み $m i$ and 〜さ $s a$. み $m i$ is a suffix that derives an adjective into a noun. さ is an objective suffix that derives an adjective into a noun. 
Example (3) below illustrates the distinction between the two.

(3) 〜 み んさ

a. 楽しみ tanoshimi: 明日のデートが楽しみです (Looking forward to the party tomorrow)

b. 楽しさ tanoshisa:旅行の楽しさは人に出会うことにある (The enjoyment of travelling resides in meeting people)

(3a) tanoshimi and (3b) tanoshisa are derived from the same adjective, tanoshii 'happy'. They are morphologically alike, but carry different semantic readings: (3a) tanoshimi describes an abstract meaning of the proposition, i.e., the party is something to be expectable, while (3b) tanoshisa renders an objective description about the proposition, here referring to 'the enjoyment of travelling'.

Another illustration of split subjectivity comes from adjectives. Japanese adjectives have two variations: $i$-adjectives (4a) and $n a$-adjectives (4b) (Note 2).

(4) a. Hanako wa kabe o shiroku nutta. $\quad(i$-adjective)

Hanako TOP wall ACC white paint.PAST

'Hanako painted the wall white.'

b. Hanako wa kabe o masshiro ni nutta. (na-adjective)

Hanako TOP wall ACC completely-white COP stretch.PAST

'Hanako painted the wall completely white.'

$i$-adjectives have two subtypes: しい-ending adjectives and $い$-ending adjectives. This is illustrated in (5).

(5) Subtypes of $i$-adjectives

a. LW-ending adjectives: ureshii 'happy'; kanashii 'sad'; sabishii 'lonely'; tanoshii 'happy', etc.

b. W-ending adjectives: buatsui 'thick'; akarui 'bright'; tsumetai 'cold', etc.

しい-ending adjectives (5a) convey a psychological/emotional meaning, as seen in ureshii 'happy'; kanashii 'sad'; sabishii 'lonely'. W-ending adjectives offer an objective description about an item or an event.

The differentiation of subjectivity in adjectives is further tied to the constraints on the personal pronoun. In assertive sentences, subjective adjectives (i.e., Lい-ending adjectives) are limited to first personal pronouns. Subjective adjectives are unavailable for third or second personal pronouns in assertive sentences. This is illustrated in (6) (Note 3).

(6) a. Watashi wa kanashii. (well-formed)

1st.sg. TOP sad

b. *Kare/Kimi wa kanashii. (ill-formed)

3rd/2nd.sg. $\quad$ TOP sad

To make subjective adjectives (i.e., しい-ending adjectives) possible for a third personal pronoun, the adjective should be transformed. There are three ways to achieve this: (a) verbalise the adjectives with the suffix 'garu', thus, the ill-formed (6b) is transformed into the well-formed 'Kare wa kanashigaru.'; (b) add to auxiliary 'sooda' to LW-ending adjectives, thus, (6b) is transformed into the well-formed 'Kare wa kanashisooda.'; (c) make the sentence as a subordinate clause by adding a complementiser と 'to' and a psychological verb 思う 'omou', thus, (6b) turns into 'Kare wa kanashii to omou.'

Split subjectivity also extends to adnominal adjectives. An example is given in (7).

\section{(7) Split subjectivity in adnominal adjectives}

a. ookii ani 'big brother': focus on the shape or size

b. ookina ani 'the older brother': focus on the age

Adnominals ookii/ookina 'big' play the role of modifying nouns. Although ookii and ookina share the same morphological features, the two carry different meanings. Ookii focuses on physical size, whilst ookina focuses on an abstract reading, e.g., the position, the age, the title, etc. Here, ookii ani refers to the brother who is tall and big. ookii ani refers to the older brother.

These are preliminary illustrations that inspire us to delve deeper into the phenomenon of subjectivity in Japanese. 


\subsection{Research Questions}

The purpose of this paper is two-fold. First, attention will be drawn to the distribution of subjectivity. To achieve this goal, nine grammatical categories are to be examined: suffixes and prefixes, adjectives, particles, auxiliaries, nouns, adnominals, adverbs and transitive/intransitive verb pairs. Second, this paper will consider whether a relationship can be mapped between transitivity, subjectivity and grammaticalisation. To this end, I will conduct an investigation into the distribution of transitive and intransitive verbs that are grammaticalised and lexicalised.

To test the subjectivity in various grammatical items, the following syntactic tests will be carried out.

(8) a. Constraint on personal pronouns. In assertive sentences, where the grammatical item is limited to the first personal pronoun, the item tends to be subjective (Note 4).

b. The agentivity of the verbs with which the grammatical item co-occurs. When a grammatical item occurs with verbs that bear strong agentivity, e.g., naguru 'beat', kiru 'chop', utsu 'shoot', etc., this grammatical item tends to be 'subjective'. When a grammatical item occurs with unaccusative verbs (with no or little agentivity), e.g., azukaru 'to look after', kurushimu 'suffer', etc., the grammatical item is objective.

c. Semantically, when a grammatical item is involved with an evaluation or an imperative. To put it another way, when it occurs with imperative auxiliaries, e.g., tekudai, the item can be characterised as subjective.

Two databases were built for the purposes of this investigation. The data for the grammatical category were drawn from the 'Tsukuba Web Corpus'. The data for verb grammaticalisation were randomly extracted from the 'Compound Verb Lexicon' corpus (http://vvlexicon.ninjal.ac.jp/en/, National Institute for Japanese Language and Linguistics).

The rest of the paper is mapped out as follows: Section 2 addresses the data and draws an overall picture of split subjectivity in different grammatical categories. Section 3 delves into the distribution of transitive V and intransitive $\mathrm{V}$ in terms of grammaticalisation, searching for how transitivity, subjectivisation and grammaticalisation are related. Section 4 highlights the results and concludes the paper.

\subsection{Grammaticalisation}

To begin the investigation, this paper will touch upon some general issues regarding grammaticalisation.

Grammaticalisation deals with the question of how a lexical item develops into a marker of a grammatical category, or how a marker representing a less grammatical function takes on a more grammatical one (Kuryłowicz, 1965; Bisang, 2011). This concept was initially put forward by Zhou Boqi, a Chinese scholar of the Yuan Dynasty (1279-1368). Zhou stated: ‘Today's function words are all former full words (今之虚字皆古之實

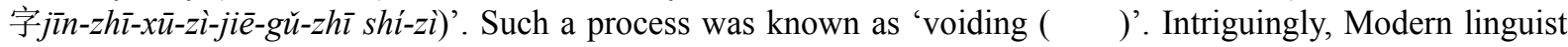
Givón $(1971,1979)$ holds a similar position: 'Today's morphology is yesterday's syntax'. Grammaticalisation, in Kurylowiczs's (1965, p. 69) regard, consists of increasing the range of a morpheme from a lexical to a grammatical (or from a less grammatical to a more grammatical) status. For instance, the English will was originally a substantive verb, meaning 'want', but was grammaticalised as an auxiliary verb, expressing the future of 'to be'. Traugott and Heine (1991) argue that, when discussing how substantive lexicons move into function words, the important factor of construction cannot be neglected, as the development of grammatical items is shaped by the constructions in which these items occur. Therefore, they refine their definition of grammaticalisation as 'the development of constructions [...] via discourse practices into more grammatical material', e.g., lexical items transit into morphological formatives. Himmelmann (2004, p. 31) contends that 'it is the grammaticising element in its syntagmatic context which is grammaticised'.

In accordance with the theme of the present research, this pilot study suggests that two grammatical categories in Japanese are particularly grammaticalised: verbs (turning substantive verbs into directional/resultative complement) and particles.

(9) a. Particles that originated in substantive verbs: 〜によって, 〜について, 〜に限って, 〜に関して, 〜 を巡って, 〜をもって, etc.

b. Particles that originated in nouns: ばかり; 程;さえ; はず;よう, etc.

c. Aspectual verbs that were originally substantive manner verbs: あがる/あげる; 切る; 終わる; 合う, etc.

It should also be pointed out that Japanese has systemic transitive/intransitive alternation pairs realised by morpheme alternation, e.g., '-e-' and '-i-'.

(10) a. Morpheme '-e-' is used with both intransitive and transitive verbs; morpheme '-ar-' represents an intransitive verb. The morpheme of its transitive verb is '-ø-(-u)'or '-e-', e.g., 
//nur-e-ru//-//nur-as-(r)u//, //kak-ar-(r)u //-//kak-e-ru//, //or-e-ru//-//or-ø-(r)u//, //at-ar-(r)u//-//at-e-ru//, //yak-e-ru//-//yak-ø-(r)u//, //tat- ø-(r)u//-//tat-e-ru//

b. Morpheme '-i-' represents an intransitive verb. The morphemes of its transitive pair are '-ø-(-u)' or '-os-(-osu)'/"-as-(-asu)'.

A question arises as to whether a grammatical item being a product of grammaticalisation is a random choice. Take the pair 切るkiru/切れるkireru, for instance. It seems that the transitive verb 切るkiru 'to cut' was grammaticalised into the resultative complement, cf. (11). In the pair 込む komu/込めるkomeru, it is the intransitive verb 込む $k o m u$ that was grammaticalised, cf. (12). There is also the third option that both transitive and intransitive are grammaticalised, e.g., 上げるageru /上がるagaru, as shown in (13).

(11) Transitive verbs receive grammaticalisation (e.g., 切る kiru)

切る kiru 'cut' is a transitive V, meaning 'to cut'. In V-V 締め切る shime-kiru 'tie-close', 切る kiru retains the syntactic function but its semantic meaning transforms into an idiomatic reading. In another V-V, 疲れ切る tsukure-kiru 'extremely exhausted', V2 kiru conveys the ASPECT, i.e., the degree of exhaustion, while V1 tsukareru is an unaccusative V, meaning 'being exhausted'. Further illustrations include 食べ切る tabekiru 'to eat up' and 言い切る iikiru 'to state definitely' (Note 5).

(12) Intransitive verbs receive grammaticalisation (e.g., 込む $k o m u$ )

込む komu is an intransitive verb. This study detected 255 tokens of komu behaving as a complement within the 'Compound Verb Lexicon' corpus. Illustrations include 打ち込む uchikomu 'to focus on; to pour all of one's energy into'，駆け込む kakekomu 'to run (with momentum) inside'.

(13) Both transitive and intransitive verbs get grammaticalised (e.g., 上げる ageru/上がる agaru)

a. 編み上げる TRAN. amiageru 'finished knitting'; 洗い上げる TRAN. araiageru 'finished washing'

b. 編み上がる ${ }_{\text {INTR. }}$ amiagaru '(Of a knitting project) to be finished'; 仕上がる ${ }_{\text {INTR. }}$ shiagaru 'to be finished.'

With the concept of grammaticalisation explained, the following sections will now proceed to the data, posing the questions of (i) how various grammatical elements display split subjectivity, and (ii) whether transitive verbs are proven likely to be grammaticalised into subjective items due to their transitivity, whilst intransitive verbs are likely to be grammaticalised into intersubjective items.

\section{The Data}

899 lexicons were drawn from 'Tsukuba Web Corpus', including: 400 transitive/intransitive verb pairs, 149 adverbs, 62 prefixes, 99 suffixes, 24 adnominal adjectives, 71 particles, 6 nouns, 79 adjectives and 9 auxiliaries. Figure 1 provides a closer examination of the data.

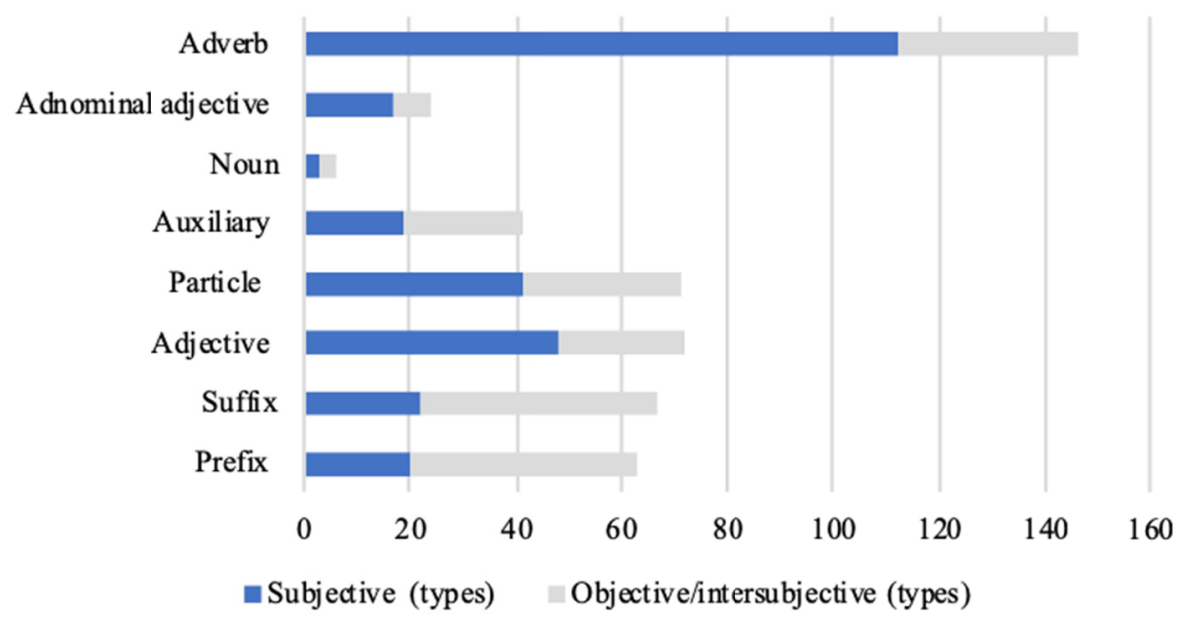

Figure 1. Grammatical items and their subjectivity

As can be confirmed by citing the frequency from the database, prefixes, suffixes and auxiliaries are likely to render an objective or intersubjective meaning. The following subsections offer a detailed analysis of the nine 
categories in focus. Our starting point is affixes.

\subsection{Subjectivity in Affixes}

Modern Japanese consists of two writing systems: moraic script and characters. Consequently, affixes are written according to two formats, i.e., wago and characters.

\subsubsection{Subjectivity in Suffixes}

There are four types of suffix in Japanese: nominalisation suffixes, verbalisation suffixes, adjective-adjectivisation suffixes and Sino-Japanese suffixes. To provide an adequate account of how subjectivity is distributed in different types of suffixes, this study calculated the frequencies of the four types of suffixes in BCCWJ. The findings are presented in Table 1.

Table 1. Subjectivity in Japanese suffixes

\begin{tabular}{|c|c|c|c|c|}
\hline Suffix & Subjective types & Illustrations & $\begin{array}{l}\text { Objective/ } \\
\text { Intersubjective types }\end{array}$ & Illustrations \\
\hline Nominalisation suffix & 4 & $\begin{array}{l}\text { かけ; げ; み;ぐるみ; ごか } \\
\text { し;だらけ }\end{array}$ & 6 & さ;け; つけ;くら;こ \\
\hline Verbalisation suffix & 8 & $\begin{array}{l}\text { がる; づく; めく; ばる; が } \\
\text { たい }\end{array}$ & 8 & びる;やぐ；じみる;ぐむ \\
\hline$i$-adjectivisation suffix & 8 & ぽい; づらい;くさい; らか & 5 & にくい; らしい; やすい; こい \\
\hline Sino-Japanese suffix & 2 & $\begin{array}{l}\text { しごく(至極)；ほうだい(放 } \\
\text { 題) }\end{array}$ & 26 & $\begin{array}{l}\text { こう (工)；か (化)；いん (院)； } \\
\text { おき (置) }\end{array}$ \\
\hline
\end{tabular}

Table 1 sheds light on five issues.

(a) Subjectivity in affixes is facilitated by phonology: voiced/voiceless consonant alternation. Take 気 for instance. When its consonant is voiced, namely, 'ge', a subjective reading is rendered. When 気 is voiceless, namely, 'ke', an objective meaning is conveyed. This strategy of consonant voicing is rather common. Further illustrations include つくtsuku/づくduku pair and their transitive counterparts: つける tsukeru/づける dukeru.

(b) Nominalisation suffixes result from grammaticalisation on transitive/ intransitive verbs. It is always the transitive verb that alters into a subjective nominalisation suffix (e.g., がけ 掛 gake), and it is the intransitive verb that is transformed into an intersubjective nominalisation suffix (e.g., がかり 掛 gakari).

(c) Sino-Japanese suffixes are mostly used in official lexicons, indicating title (e.g., 公 koo 'official'), a period (e.g., 時 ji 'era' [kakumeiji 'revolutionary era']), profession (e.g., 師 shi [yakuzaishi 'pharmacist']), quantities, (e.g., 三貫 sankan), plurals (e.g., 方 kata [senseigata 'teachers']) or a specific function (e.g., 工 koo), etc. Sino-Japanese suffixes involve neither personal evaluations nor judgements and are objective.

(d) Suffixes involve grammaticalisation. Most suffixes result from grammaticalisation in substantive adjectives (e.g., kusai), verbs (e.g., tsuku), nouns (e.g., hoodai) and others. It should be pointed out that when a lexical item is fully grammaticalised into a function word, yielding ASPECT or RESULT, the lexical item is written in kana (phonetic script). Crucially, not all lexicons are fully grammaticalised into function words; some lexicons are partially grammaticalised. Suffixes are therefore double-faced: when the suffix functions as a substantive lexicon, it is written in wago, and when the it behaves as a function word, it is written in kana. For instance, kusai 'smelly' has two faces; 臭い kusai is a substantive adjective whilst 〈さい kusai is a suffix.

(e) A suffix may render a subjective meaning in one circumstance and an objective meaning in another.

Perhaps a specific example of split subjectivity in a suffix is necessary to illustrate this. にくい nikui and づら $い$ durai are suffixes that render a similar meaning: 'hard to do something'. In BCCWJ, suffix nikui derives 6152 tokens of verbs into an adjective. $77 \%$ of the tokens denote co-occurrence with verbs that are non-agentive (involutional); $9 \%$ of the tokens goes to verbs in the passive voice; $6 \%$ of the tokens are verbs in possibility modal. Among the 857 tokens of suffix durai, $91 \%$ goes to volitional verbs. This inspires us to ponder that suffix durai is subjective while nikui is objective.

Another typical illustration of split subjectivity in suffixes is the pair of 〜よい〜やすい, which is provided in (14).

(14) 〜よい/ややすい 
a. hakiyoi: I feel comfortable about the shoes (but others may not feel the same way. The shoes may not be comfortable (in other customers' regard)

b. hakiyasui: The shoes themselves are highly qualified and thus are comfortable (other customers feel the same way)

よい yoi 'good to do something' and やすい yasui 'easy to do something' are a pair of suffixes that render similar meanings and can derive a verb into an adjective. The subjectivity they yield, however, is different. よい yoi seems subjective, as exemplified by (3a); hakiyoi focuses on the evaluation of the utterer, namely 'I feel comfortable about the shoes. It could be only me who feel that way; others may not find the shoes comfortable'. やすい yasui focuses on the target of the proposition itself, describing the shoes as highly qualified and comfortable. There is an implication that 'it is not just me that feels like way; other customers do as well'. Incorporating this, yasui conveys an objective meaning.

\subsubsection{Subjectivity in Prefixes}

Unlike suffixes, where wago plays a crucial role, most prefixes are written in Sino-Japanese (68\% of prefixes in our database are written in Sino-Japanese). (15) provides illustrations of wago-prefix and Sino-Japanese prefix.

(15) Two writings of prefixes

Wago: (20 types in total), e.g., す; こ; 相; 真; うわ; おお; き;す; いく; から;さ（五月・㿞）

Sino-Japanese: (43 types in total), e.g., 該; 各; 環; 旧; 再; 諸; 純; 全; 前; 大; 被; 不; 無; 未; 高; 低; 今; 超; 両

The top ten most frequent prefixes, along with their subjectivity, are listed in Table 2.

Table 2. Subjectivity in Japanese prefixes

\begin{tabular}{llll}
\hline Prefix & Tokens & Subjectivity & Subjectivity \\
\hline 全 & 368,345 & Subjective & \\
各 & 289,290 & & Objective \\
約 & 251,388 & & Objective \\
同 & 178,151 & & Objective \\
当 & 176,521 & & Objective \\
新 & 156,086 & & Objective \\
前 & 101,293 & Subjective & \\
元 & 72,196 & & Objective \\
非 & 94,517 & & Objective \\
小 & 85,167 & & Objective \\
\hline
\end{tabular}

Prefixes of negation are particularly worthy of further discussion. This study classifies prefixes of negation into three groups: objective prefixes, subjective prefixes and double-faced prefixes, as shown in (16).

(16) Prefixes of negation

a. absolutely intersubjective prefix: 未 $m i$ (corresponding to English 'not yet')

e.g., 未成年 miseinen 'minor', 未開発 mikaihatsu 'underdevelopment'

b. absolutely subjective prefix: 非 $h i$ (corresponding to English prefix un)

e.g., 非文法的 hibunpooteki 'ungrammatical'

c. double-faced prefixes: 不; 無.

The double-faced prefixes 不 and 無 warrant further discussion. When 不 is pronounced $f u$, it derives a meaning of 'opposite' (17). Illustrations include 不得意 futokui 'not good at sth'; 不規則的 fukisokuteki 'unregularly'. In this regard, an objective reading is rendered.

(17) 不 $\boldsymbol{f u}$ (Intersubjective)

Corresponding to English prefixes un and im

e.g., 不得意 futokui 'not good at sth'; 不規則的 fukisokuteki 'unregularly'; 不可能 fukanoo 'impossible'; 不自然 fushizen 'unnatural'; 不干涉 fukanshoo 'not-interfere'.

When 不 is pronounced $b u$, an evaluation or judgement from the utterer is involved and subjective reading is 
yielded. Illustrations include 不気味 bukimi 'eerily'; 不器用bukiyoo 'heavy-handed'.

\section{(18) 不 $\boldsymbol{b u}$ (Subjective)}

e.g., 不気味 bukimi 'eerily'; 不器用 bukiyoo 'heavy-handed'; 不器量 bukiryoo 'plain'; 不調法 buchoohoo 'wrongful conduct'

Another double-faced negative prefix is 無. When 無 is pronounced $m u$, an objective reading is conveyed, meaning 'without something', as seen in 無資格 mushikaku 'without qualification'; 無責任 musekinin 'without responsibility'. In this regard, the function of 無 resembles English suffix less:

(19) 無 $\boldsymbol{m u}$ (Intersubjective) Corresponding to English suffix less

e.g., 無資格 mushikaku 'without qualification'; 無責任 musekinin 'without responsibility’; 無免許 mumenkyoo 'without license'

When 無 is pronounced $b u$, a subjective reading is suggested. Examples include 無愛想 buaisoo 'unfriendly'. 無愛想 describs a person's character, here meaning 'unfriendly'.

We might pause here and put forward the suggestion that prefixes with a voiced consonant (e.g., $b u$ ) render a subjective semantic meaning, while prefixes with a voiceless consonant tend to yield an objective reading. This phonological principle also applies to suffixes, which will be addressed shortly.

There is another prefix pair that displays split subjectivity and presents the voiced/voiceless principle, i.e., prefix 前 zen (101,293 tokens) and 元 moto (72,196 tokens). These two prefixes carry similar semantic meanings.

Phonologically, 前 zen is onyomi while 元 moto is kunyomi (Note 6). The differentiation is tied to the ASPECT and subjectivity. Comparative illustrations are given in (20).

(20) a. 「元-」：元夫 moto-otto 'a one-time band' (83 tokens), 元記事 moto-kiji 'a one-time news' (35 tokens), 元同僚 moto-kanryoo 'a one-time colleague' (18 tokens), 元サイト moto-saito 'a one-time site', etc.

b. 「前-」：前夫 zen-otto 'ex-husband' (64 tokens), 前記事 zen-kiji (32 tokens), 前政権 zen-seiken, 前バー ジョン zen-baajon, 前世代 zen-sedai, etc.

前 is related to 'spatial', meaning 'immediately before'. 元 focuses on 'affiliation'. Take 前夫/元夫, for instance; 前夫 refers to the previous husband. Essentially, there is only one 'previous husband'. With 元夫, there might be three or more husbands. Given this, it appears that prefix 前 is equal to English prefix ex and can be alleged as rendering a 'spatial semantic meaning'. 元 carries an affiliation focus, meaning 'a one-time...'.

\subsection{Split Subjectivity in Adjectives}

Let us now move on to adjectives. Before attempting to delve into the subjectivity of an adjective, it is necessary to clarify its type. Earlier, I touched upon the fact that there are two subtypes of Japanese $i$-adjectives, i.e., LW -ending adjectives and $W$-ending adjectives. Table 3 presents the distinctions between the two.

Table 3. Split subjectivity in Japanese adjectives

\begin{tabular}{lllll}
\hline Adj & Subjective types & Illustrations & Objective types & Illustrations \\
\hline しい ending & 45 & 呪わしい; 誇らしい; 怪しい; 寂しい & 2 & 涼しい; 優しい (Note 7) \\
い ending & 3 & 心細い; 物憂い; 憎い & 22 & 明るい; 厚い; 寒い; 暑い \\
\hline
\end{tabular}

しい-ending adjectives are subjective, and $い$-ending adjectives are objective. There are three further distinctions between $し い$-ending adjectives and $い$-ending adjectives, i.e., personal pronoun constraints, verbalisation possibility and occurrence with the adverb zuibun, as summarised in Table 4.

Table 4. Distinctions between subjective adjectives and objective adjectives

\begin{tabular}{lll}
\hline & Subjective Adj (しい ending) & Objective Adj ( ending) \\
\hline Personal pronoun constraint & 1st personal pronoun only & No constraint \\
Verbalisation & Realised by suffix 'garu' & $\times$ \\
Co-occurrence with Adv zuibun & $\times$ & $\circ$ \\
\hline
\end{tabular}

(a) First, subjective Adj (しい-ending) is limited to the first personal pronoun, whilst objective Adj (い-ending) does not have such a constraint. 
(b) Second, the verbalisation suffix garu can only derive subjective Adj (しい-ending) into a verb, with objective Adj ( $($-ending) being ruled out.

(c) Third, intersubjective Adj ( $\backslash$-ending) may be modified by the adverb zuibun whilst subjective Adj (Lい -ending) may not.

It is also intriguing to note that the objective / subjective reading is switchable. For example, the suffix つぽい may help objective Adj alter into a subjective reading. (21a) 青い aoi denotes an objective description of colour, i.e., blue. The suffix つぽい adds an evaluation to the colour, thus transforming 青つぽい into 'sth is blue-like ....'.

(21) a. 青い objective reading e.g., 青いジャケット (a blue jacket) blue))

b. 青っぽい subjective reading, e.g., 青っぽいジャケット (a jacket that appears to be blue-like (not exactly

\subsection{Subjectivity in Auxiliaries}

This study will now turn to auxiliaries. The database reveals that 19 types of Japanese auxiliary apply to subjective use and 22 types denote an objective meaning. Table 5 illustrates this data.

Table 5. Subjectivity in Japanese auxiliaries

\begin{tabular}{lll}
\hline Auxiliary & Tokens & Subjectivity \\
\hline$ん$ & $2,498,405$ & Subjective \\
たい & $1,455,148$ & Subjective \\
ぶし & 498,369 & Subjective \\
なり & 82,907 & Subjective \\
わ & 79,365 & Subjective \\
& 72,946 & Objective \\
や & 55,381 & Subjective \\
じ & 54,320 & Subjective \\
き & 51,737 & Subjective \\
たり & 49,170 & Intersubjective \\
はず & 31,267 & Subjective \\
\hline
\end{tabular}

Let us take a closer look at subjective/objective pair はず hazu/わけ wake.

$\begin{array}{ccccc}\text { (22) a. } 1000 \text { meetoru } & \text { no koogen dakara, } & \text { suzushii hazuda. } \\ 1000 \text { metre } & \text { GEN } & \text { plateau be.CONJ } & \text { cool must be }\end{array}$

'It is 1000-metre plateau, so it must be cool.'

b. 1000 meetoru no koogen dakara, suzushii wakeda.

1000 metre GEN plateau be.CONJ cool no wonder

'It is 1000-metre plateau, no wonder it is cool.'

(22a) employs the auxiliary hazu. The sentence means that the utterer has not yet arrived at the plateau. The description of the plateau is an assumption of the utterer, which resembles the English auxiliary 'must be'. Given this, the auxiliary hazu is subjective. (22b)'s description is based upon the fact that the place is a plateau, and it is therefore no wonder that it is cool. The auxiliary wake renders an intersubjective reading.

Split subjectivity in auxiliaries can also be observed in the pair kiri/dake. kiri renders a situation and is objective, as can be seen in (23a). Dake conveys a subjective reading: how sad/lonely, there are only two people, cf. (23b).

(23) a. futari kiri: only two people

b. futari dake: only two people, (how sad/disappointing/lonely)

\subsection{Subjectivity in Particles}

This section proceeds by looking into subjectivity in particles. 71 types of particles were detected. Table 6 extracts the particles whose frequencies were in the top 10. 
Table 6. Illustrations of Japanese particles

\begin{tabular}{llll}
\hline Particle & Tokens & Subjectivity & Subjectivity \\
\hline や & $3,763,509$ & Subjective & \\
として & $2,071,620$ & Subjective & \\
ね & $1,406,384$ & & Intersubjective \\
$\sim$ & $1,360,690$ & & Objective \\
について & $1,345,645$ & & Objective \\
たり & 969,082 & Subjective & \\
よ & 884,361 & Subjective & \\
とは & 861,233 & & Objective \\
でも & 758,487 & Subjective & \\
によって & 752,883 & & Objective \\
よ & 884,361 & Subjective & \\
\hline
\end{tabular}

It was discovered that 41 types of particles render a subjective reading; one is intersubjective and 29 are objective. To further confirm the findings, this study selects final particles ne and $y o$ as candidates for a detailed discussion. Previous research mostly regards ne as emphasising the information shared by both utterer and the hearer (e.g., Kamio, 1990; Masuoka, 1991; Ohso, 1996). An example is given in (24).
(24) a. O Shima tte
HON Shima COMP queer
kawatta na desu
PART
ne. (Intersubjective)
'The name Shima sounds queer, isn't it?'
b. O Shima tte
kawatta na desu
yo. (Intersubjective)
HON Shima COMP queer
name PRED
PART

'It seems to me that the name Shima is queer.'

Following Masuoka (1991, p. 96), the final particle ne indicates that the utterer and the hearer share the same opinion that Shima is a 'queer name' (24a). The final particle yo indicates that it is the utterer who finds the name Shima queer (24b). The semantic scope excludes the hearer.

\subsection{Subjectivity in Adverbs}

Split subjectivity is further observed in adverbs. In the database, there are 112 types of adverbs with a subjective reading, and 34 types that are objective or intersubjective. Adverb subjectivity is shown in Table 7.

Table 7. Subjectivity in Japanese adverbs

\begin{tabular}{lll}
\hline Auxiliary & Tokens & Subjectivity \\
\hline 最 & 12,862 & subjective \\
だろう & 75,631 & subjective \\
まい & 45,786 & subjective \\
きっと & 7,678 & objective \\
たぶん & 4,482 & intersubjective \\
もっ & 26,002 & subjective \\
もちろん & 19,415 & objective \\
おとらく & 6,183 & objective \\
果たして & 3,225 & objective \\
まさしく & 1,007 & objective \\
当然 & 13,095 & objective \\
しっり & 158,129 & subjective \\
いつも & 153,947 & subjective \\
もちん & 19,415 & objective \\
決して & 7,584 & subjective \\
\hline
\end{tabular}

A typical example would be kitto/osoraku, cf. (25).
(25) a. Kare wa kitto
kuru.
(Subjective)
He TOP absolutely
come

'He will absolutely come.' 


$$
\begin{aligned}
& \text { b. Kare wa } \text { osoraku } \quad \text { kuru. (Objective) } \\
& \mathrm{He} \text { TOP perhaps come }
\end{aligned}
$$

'He might come.'

In (25a), the utterer strongly believes he will come. The adverb kitto is subjective. In (25b), the adverb osoraku suggests that there is a sign that 'he might come'. The adverb Osoraku conveys an objective reading.

\subsection{Subjectivity in Nouns}

The study will now proceed to a more detailed look at split subjectivity in nouns. The following example is an illustration of subjectivity represented by nouns; tsumori 'want to do sth' renders a subjective reading, while its objective correspondence is yotei 'be going to do sth'.

(26) tsumori: plan (wants to do sth.)

Ashita toshokan ni iku tsumori da.

Tomorrow library DAT go plan PRED

'I plan to go to library tomorrow.'

(27) yotei: schedule (be going to do sth.)

Ashita toshokan ni iku yotei da.

Tomorrow library DAT go schedule PRED

'I am going to library tomorrow.'

Six nouns are detected and are listed in Table 8.

Table 8. Subjectivity in Japanese nouns

\begin{tabular}{llll}
\hline Subjective N & BCCWJ frequency & Intersubjective $\mathbf{~}$ & BCCWJ frequency \\
\hline$よ う$ & $3,866,384$ & ため & $2,050,274$ \\
これ & $1,664,172$ & それ & $1,626,239$ \\
つもり & 11,078 & 予定 & 13,516 \\
\hline
\end{tabular}

It is also important to notice that, in addition to affixes, adjectives, auxiliaries, particles, adverbs and nouns, subjectivity can be seen in adnominals. This is illustrated in Table 9.

Table 9. Subjectivity in adnominals

\begin{tabular}{llll}
\hline Adnominal adjectives & Tokens & Subjectivity & Subjectivity \\
\hline その & $3,560,026$ & & Intersubjective \\
この & $2,997,132$ & Subjective & \\
同じ & 512,045 & & Intersubjective \\
ぞの & 393,712 & Subjective & \\
大きな & 355,015 & Subjective & Objective \\
そんな & 334,715 & & Objective \\
そういう & 285,432 & & \\
こんな & 188,759 & Subjective & Intersubjective \\
ある & 160,155 & & \\
これらの & 150,191 & Subjective & \\
あの & 131,496 & Subjective & \\
こういう & 129,589 & Subjective & \\
こうした & 121,330 & Subjective & \\
ごういう & 92,132 & Subjective & \\
いわゆる & 80,146 & Subjective & \\
いろんな & 66,320 & Subjective & \\
そういった & 65,044 & & \\
そうした & 62,943 & Subjective & \\
あらゆる & 60,964 & Subjective & \\
何らかの & 40,477 & Subjective & \\
それらの & 40,252 & & Objective \\
いかなる & 24,282 & Subjective & \\
ほんの & 24,220 & Subjective & \\
ちよつとした & 23,298 & Subjective & \\
\hline
\end{tabular}




\subsection{Summary}

So far, discussions have focused on how split subjectivity is represented in grammatical categories. The frequency of adnominals and auxiliaries in subjective use is considerably higher in comparison to objective use. Adverbs and prefixes tend to render an objective/intersubjective reading. The conclusion that one can draw here is that Japanese is a subjective/objective-split language. The following section proceeds to explore how subjectivity, grammaticalisation and transitivity are related. Verbs were selected as candidates for the investigation, along with the long-term transition of the Japanese language and how lexicons are grammaticalised (thus to play a functional role) or lexicalised to bear a subjective meaning.

\section{Grammaticalisation, Lexicalisation and Subjectivisation}

400 transitive/intransitive verb pairs were extracted from the list 'transitive/intransitive verb pair' http://watp.ninjal.ac.jp/resources/. They were grouped into (a) pairs of change-of-state verbs and motion verbs; (b) pairs of perception verbs.

It was observed that the majority of verb alternations come about thanks to motion and change-of-state. Table 10 presents some illustrations of motion and change-of-state verbs.

Table 10. Transitive/intransitive verb pairs regarding change of state and motion

\begin{tabular}{llllll}
\hline Intransitive V & BCCWJ frequency & Subjectivity & Transitive V & BCCWJ frequency & Subjectivity \\
\hline 会う & 12,589 & Objective & 会わす & 18 & Subjective \\
動く & 9,676 & Objective & 動かす & 4,880 & Subjective \\
驚く & 8,020 & Objective & 驚かす & 530 & Subjective \\
困る & 8,746 & Objective & 困らす & 12 & Subjective \\
住む & 10,606 & Objective & 住ます & 1 & Subjective \\
飛ぶ & 5,360 & Objective & 飛ばす & 1,476 & Subjective \\
泣く & 6,061 & Objective & 泣かす & 127 & Subjective \\
喜ぶ & 5,343 & Objective & 喜ばす & 49 & Subjective \\
笑う & 10,527 & Objective & 笑わす & 31 & Subjective \\
生きる & 16,844 & Objective & 生かす & 3,396 & Subjective \\
起きる & 9,757 & Objective & 起こす & 7,253 & Subjective \\
落ちる & 8,374 & Objective & 落とす & 4,871 & Subjective \\
\hline
\end{tabular}

In light of the distribution of subjectivity, we will now proceed to examine the possibilities for grammaticalisation and lexicalisation within the verb pairs. An examination in terms of syntactic compound verbs was carried out. The reason for selecting syntactic compound verbs was due to the fact that, in syntactic $\mathrm{V}-\mathrm{Vs}$, the V1 conveys ACTION and the V2 renders RESULT or ASPECT of the action. V2s are most likely to be grammaticalised into a resultative complement or directional complement.

A brief search on syntactic V-Vs in the database reveals that there are unaccusative verbs that only serve as V2 and never serve as the V1 in a compound verb. This is shown in Table 11.

Table 11. Unaccusatives that only serve V2

\begin{tabular}{llllll}
\hline Verb & Transitivity & As V1 & Tokens & As V2 & Tokens \\
\hline 込む & Unacc. & 込む & 0 & 込む & 64 \\
合う & Unacc. & 合う & 0 & 合う & 27 \\
かかる & Unacc. & かかる & 0 & かかる & 10 \\
\hline
\end{tabular}

The above data might suggest that the degree of grammaticalisation on komu, au and kakaru is high, which suggests that intransitive verbs are likely to be grammaticalised into resultative complements. At this stage, another issue arises: what about transitive verbs? Are they likely to be lexicalised, thus carrying a subjective reading? To answer this inquiry, this study selects a typical change-of-state verb, kiru 'to cut', examining its functions as grammaticalised aspectual verb and lexicalised transitive verb.

kiru was originally a transitive verb, carrying the meaning 'to cut'. A quick search in the corpus 'Compound Verb Lexicon' reveals that kiru builds 28 verb compounds with different V1 verbs. kiru may follow a transitive V (e.g., kami-kiru 'cut off something with teeth'). In this V-V, kiru may indicate a substantive meaning. When it follows an unaccusative $\mathrm{V}$, as seen in tsukure-kiru 'extremely exhausted', V1 tsukareru is an unaccusative V, 
meaning 'being exhausted' and V2 kiru conveys the ASPECT, describing the degree of exhaustion. The V-V means 'extremely exhausted'.

Table 12. A case study on subjectivity and grammaticalisation

\begin{tabular}{llllll}
\hline $\mathbf{V}-\mathbf{V}$ & $\mathbf{V 1}$ & $\mathbf{V 2}$ & $\begin{array}{l}\text { Subjectivity of } \\
\boldsymbol{k i r u} \text { as V2 }\end{array}$ & Diachronic shift & $\begin{array}{l}\text { Degree of } \\
\text { grammaticalisation }\end{array}$ \\
\hline 噛み切る & 噛む transitive & transitive & High & none & Not grammaticalised \\
締め切る & 締める transitive & transitive & & lexicalisation involved & \\
食べ切る & 食べる transitive & ?transitive/aspectual V & & grammaticalisation involved & Partial grammaticalised \\
言い切る & 言う transitive & aspectual V & & grammaticalisation involved & Fully grammaticalised \\
乗り切る & 乗る unaccusative & aspectual V & & grammaticalisation involved & Fully grammaticalised \\
疲れ切る & 疲れる unaccusative & aspectual V & low & grammaticalisation involved & Fully grammaticalised \\
\hline
\end{tabular}

It appears that the selection of kiru's multiple characteristics (as a substantive transitive verb or an aspectual verb) relies on the first constituent. When kiru pairs with a transitive $\mathrm{V}$ that bears strong agentivity, e.g., 噛む kamu 'to bite', it functions as a substantive verb, whereas when kiru pairs with a transitive $\mathrm{V}$ that bears less agentivity (e.g., 締める shimeru 'fasten'), it behaves like a lexicalised verb, rendering a metaphorical meaning. When kiru pairs with a transitive $\mathrm{V}$ of low agentivity (e.g., 言う iu 'to say', 乗る noru 'get on', 疲れる tsukareru 'be tired'), it turns out to be an aspectual verb.

Another change-of-state verb that is double-faced, namely dasu 'out', exhibits a similar picture. In coordinate $\mathrm{V}-\mathrm{V}$ keri-dasu 'kick-take out', both V1 keru 'kick' and V2 dasu 'take out' involve strong agentivity. iu 'say' and omou 'think/remember' are less agentive. V2 dasu therefore behaves like a function word, rendering ASPECT, cf. ii-dasu 'say-out'; omoi-dasu 'think/remember-out'. The selection of dasu's multiple faces are provided in (28).

(28) The selection of change-of-state verbs' multiple functions (e.g., dasu)

\begin{tabular}{|c|c|c|c|c|}
\hline $\mathrm{V}-\mathrm{V}$ & V1 & Agentivity & Subjectivity & \\
\hline $\begin{array}{l}\text { keridasu (dasu as substantive V) } \\
\text { Coordinate V-V }\end{array}$ & keru & Transitive & Subjective & high \\
\hline $\begin{array}{l}\text { uridasu (?dasu as substantive V) } \\
\text { [v' V [V-aspect]] }\end{array}$ & uru & Transitive & Intersubjective & \\
\hline $\begin{array}{l}\text { iidasu (dasu as an aspectual V) } \\
\text { [v'V [V-aspect]] }\end{array}$ & $i u$ & Transitive & Intersubjective & \\
\hline $\begin{array}{l}\text { omoidasu (dasu as an aspectual V) } \\
\text { [v'V [V-aspect }]]\end{array}$ & omou & Unaccusative & Intersubjective & low \\
\hline
\end{tabular}

Having looked into change-of-state verbs, a further look at the data from motion verbs might shed more light on this issue. Let us consider the motion verb agaru. When paired with a verb of low agentivity, cf. verbs in (29 a-f), agaru renders ASPECT, forming [Transitive + Unaccusative] V-Vs or [Unergative + Unaccusative] V-Vs. It should be noted that it is not the verb type that matters, but the agentivity. When agaru is paired with a verb with high agentivity, as seen in (29g) mai-agaru, agaru retains its substantive meaning 'ascend'.

(29) The selection of motion verbs' multiple functions (agaru)

\begin{tabular}{lllll}
\hline $\mathbf{V - V}$ & $\mathbf{V 1}$ & Transitivity & V2 & Transitivity \\
\hline $\mathrm{a}$ 編み上がる & 編む & Vtran. & 上がる & Unacc. \\
$\mathrm{b}$ 洗い上がる & 洗う & Vtran. & 上がる & Unacc. \\
$\mathrm{c}$ 売り上がる & 売る & Vtran. & 上がる & Unacc. \\
$\mathrm{d}$ 思い上がる & 思う & Unerg. & 上がる & Unacc. \\
$\mathrm{e}$ 織り上がる & 織る & Vtran. & 上がる & Unacc. \\
$\mathrm{f}$ 買い上がる & 買う & Vtran. & 上がる & Unacc. \\
$\mathrm{g}$ 舞い上がる & 舞う & Unerg. & 上がる & Unerg. \\
\hline
\end{tabular}

Having confirmed our findings with change-of-state verbs and motion verbs, at this point we may put forward a proposal. 


\section{Proposal:}

Among transitive/intransitive verb pairs, the intransitive verbs are likely to get grammaticalised, while the transitive verbs are likely to be lexicalised and thus render a subjective reading. The degree of grammaticalisation, however, differs and relies on the V1. That is to say, in V-V formations whereby the V2 is rendered by a partially grammaticalised verb, the higher the agentivity of the first constituent, the more likely it is that the partially grammaticalised V2 will function as a substantive verb. The lower the V1 agentivity, the more likely it is that the partially grammaticalised V2 will behave as a functional morpheme conveying ASPECT. This result supports Li's (2018) proposal: it is the intransitive function that is subject to grammaticalisation, and it is the transitive function that is subject to lexicalisation. The interrelationship of the two processes is orthogonal.

In addition to change-of-state verbs and motion verbs, there is also a third type of verb, i.e., perception verb pairs. A list of perception verbs is provided in Table 13.

Table 13. Split subjectivity in perception verb pairs

\begin{tabular}{llllll}
\hline Transitive & BCCWJ frequency & Subjectivity & Intransitive & BCCWJ frequency & Subjectivity \\
\hline 見る & 110611 & Subjective & 見える & 30062 & Objective \\
聞く & 47766 & Subjective & 聞こえる & 7233 & Objective \\
嗅ぐ & 86 & Subjective & No correspondence & & No correspondence \\
匂う & 246 & Subjective & 包いがする & 184 & Objective \\
\hline
\end{tabular}

As far as Table 12 is concerned, perception verbs present a clear-cut subjective/objective dichotomy. Transitive perception verbs render a subjective reading, while intransitive perception verbs are likely to denote an objective reading and do not seem to be favoured as subjective perception verbs. A typical illustration of the split subjectivity would be the 見る/見える pair.

(30) 見る/見える

a. 天気 がいい ので、東京 から 富士山 を を 見る こと が できる.
tenki NOM good CONJ Tokyo from Fuji mountain ACC see NMLZ NOM do

'Because the weather is good, it is possible to see mount Fuji from Tokyo.'

$\begin{array}{rllllll}\text { b. 天気 が } & \text { い } & \text { ので、東京 } & \text { から } & \text { 富士山 } & \text { が 見える. } \\ \text { tenki NOM } & \text { good } & \text { CONJ } & \text { Tokyo } & \text { from } & \text { Fuji mountain } & \text { NOM visible }\end{array}$

'Because the weather is good, even from Tokyo mount Fuji is visible.'

Transitive perception verbs (e.g., 見る 'to see’; 聞く ‘to hear'; 匂う 'to smell'; 嗅ぐ 'to smell') take the accusative case particle $o$, and intransitive perception verbs (e.g., 見える; 聞こえる; 匂いがする) take the nominal case particle $g a$. In (30a), the subject of the action 見る has to be animate. 見える (cf. 30b) is a state verb and requires an inanimate subject. The finding in perception verb pairs comes to support the assumption that transitive verbs are likely to render a subjective reading, whilst intransitive verbs are likely to convey an objective reading.

\section{Conclusion}

This paper examined data from nine grammatical categories in an effort to shed light on the distribution of subjectivity in Japanese. The findings reveal that Japanese is a subjective/objective-split language; specifically,

(a) Subjectivity in affixes is facilitated by phonology: voiced/voiceless consonant alternation. A consonant-voiced prefix and suffix yield a subjective reading, and a consonant-voiceless prefix and suffix render an objective meaning.

(b) It is always the transitive verb that alters into a subjective nominalisation suffix, and it is the intransitive verb that transforms into an intersubjective nominalisation suffix.

(c) Sino-Japanese suffixes involve neither personal evaluations nor judgements, and thus tend to yield an objective or intersubjective meaning.

(d) The split subjectivity in adjectives is realised by morphology. しい-ending adjectives are subjective and $い$ -ending adjectives are objective. There are three distinctions between the two types, i.e., personal pronoun 
constraints, verbalisation possibility and occurrence with the adverb. Crucially, objective/subjective reading is switchable.

(e) Furthermore, among transitive/intransitive verb pairs, the intransitive verbs are likely to get grammaticalised and the transitive verbs are likely to be lexicalised and thus render a subjective reading. This is confirmed by change-of-state verbs and motion verbs. The interrelationship of grammaticalisation and lexicalisation is orthogonal.

$\begin{array}{ll}\text { Abbreviations } \\ \text { ACC } & \text { accusative } \\ \text { ADV } & \text { adverb } \\ \text { COMP } & \text { complementiser } \\ \text { COP } & \text { copula } \\ \text { COS } & \text { change-of-state } \\ \text { DAT } & \text { dative } \\ \text { FOC } & \text { focus } \\ \text { HON } & \text { honorific } \\ \text { NEG } & \text { negative } \\ \text { PASS } & \text { passive } \\ \text { PART } & \text { participle } \\ \text { PREF } & \text { prefix } \\ \text { TOP } & \text { topic }\end{array}$

\section{References}

Akasegawa, S. (2019). NLT 1.30 frequency list. Retrieved from http://nlt.tsukuba.lagoinst.info

Benveniste, É. (1971). Problems in general linguistics. Florida: University of Miami Press.

Bisang, W. (1992). Das Verb im Chinesischen, Hmong, Vietnamesischen, Thai und Khmer. Tübingen: Narr.

Compound Verb Lexicon' corpus. Retrieved from http://vvlexicon.ninjal.ac.jp/en/

Givón, T. (1971). Historical syntax and synchronic morphology. Chicago Linguistic Society Proceedings, 7 , 394-415.

Givón, T. (1979). On Understanding Grammar. New York: Academic Press.

Himmelmann, N. P. (2004). Lexicalization and grammaticalization: Opposite or orthogonal? In H. Bisang \& Wiemer (Eds.), What makes Grammaticalization? A Look from its Fringes and its Components (pp. 19-40). Berlin: Mouton de Gruyter.

Kamio, A. (1990). The theory of territory of information: a functional linguistic analysis of language. Taishukan Publishing.

Kuryłowicz, J. (1965). The evolution of grammatical categories. Diogenes, 51, 55-71. https://doi.org/10.1177/039219216501305105

Kuryłowicz, J. (1975). Esquisses linguisique II. München: W: Fink.

Langacker, R. W. (1987). Foundations of cognitive grammar (Vol. I: Theoretical prerequisites). Stanford: Stanford University Press.

Li, W. C. (2018). Grammaticalisation and lexicalisation of the Chinese verb duàn. Acta Linguistica Asiatica, 8(2), 111-137. https://doi.org/10.4312/ala.8.2.111-137

Lyons, J. (1977). Semantics (Vol. 2). Cambridge: Cambridge University Press.

Masuoka, T. (1991). Modality in Grammar. Kuroshio. Kuroshio Publishing.

Ohso, M. (1986). On the misuse of 'kyo wa ii tenki desune - hai, sudesu'. Journal of Japanese Linguistics, 5, 9.

Traugott, E. C. (2010). Regularity in semantic change. Cambridge: CUP.

Traugott, E. C., \& Bernd, H. (1991). Approaches to Grammaticalization. John Benjamins Publishing Company. 


\section{Notes}

Note 1. This paper is based on work that was supported by the National Foundation of Social Sciences (15CYY002) as well as the Humanities and Social Sciences Research Programme of Zhejiang University to Wenchao Li.

Note 2. $i$-adjectives will be the primary focus in the present study; $n a$-adjectives will not be tackled.

Note 3. The glossing follows 'Leipzig Glossing Rules'. A list of abbreviation is provided in the end of the text.

Note 4. Grammatical items that are limited to the first personal pronoun may also appear possible for the second personal pronoun in an interrogative sentence.

Note 5. Note that there is another path of diachronic change in 切る, i.e., lexicalisation. For instance, 乗り切る norikiru, meaning 'to overcome the difficulties that arise when one is heading towards one's goal'.

Note 6. Onyomi is close to the Chinese language and kunyomi is the pronunciation of traditional Japanese language.

Note 7. It should be pointed out that there is one adjective that carries two faces, i.e., 優しい. It can render a subjective reading 'gentle, kind' as in Kanojo wa yasashii (She is kind), as well as an objective meaning 'easy', e.g., Shiken wa yasashii (The test is easy).

\section{Copyrights}

Copyright for this article is retained by the author, with first publication rights granted to the journal.

This is an open-access article distributed under the terms and conditions of the Creative Commons Attribution license (http://creativecommons.org/licenses/by/4.0/). 